period of secular elevation, accompanied by faulting on an extensive scale. Gradual uprise of the land was continued practically into modern times." An epoch of extensive glaciation, with the formation of an ice-sheet in the basin of Boulder Lake, then opened in Pliocene or postPliocene times (p. 22). Especial attention is directed in this bulletin to the immense deposits of limonite iron-ore associated in the district with an ancient series of carbonate rocks. The ore is ascribed to the decay of iron pyrites, and to the reaction of the resulting ferrous sulphate on the carbonates. The ferrous carbonate has finally been altered to limonite, probably as a surface-phenomenon; but the resulting ores occur on a vast scale, highly encouraging for their future prospects (pp. 75-88).

The Bureau of Science of the Government of the Philippine Islands is responsible for the admirably produced Philippine Journal of Science, an example to our Government printers in India, or perhaps an example of the disparity of the funds officially devoted in the two countries to scientific publications. In vol. ii., No. 4 (Manila, August, 1907), Mr. A. J. Eveland describes the geology and geography of the Baguio mineral district. Here again, in the island of Luzon, we find an old crystalline basis, marine Eocene (?) and Miocene beds laid down upon it, and then an epoch of elevation and denudation. The Miocene limestone is cut through by the present Bued River valley, which reaches down to the basal diorite (Fig. 2). G. A. J. C.

\section{ARCHAOLOGY IN AMERICA.1}

THE first part of the second volume of the Transactions of the Universitv of Pennsylvania's Department of Archæology, Free Museum of Science and Art (it is a pity that this cumbrous title cannot be simplified), contains the usual instalment of articles on Cretan and Mexican archæology, with interesting contributions by $\mathrm{Mr}$. G. B. Gordon on the western Eskimo of Alaska and on an engraved bone from Ohio, the decoration of which is very Mexican in character. The author of the article on Mexican archæology, Miss Adela Breton, draws interesting analogies between the Mexican conventional representations of serpents and the dragons of Chino-Japanese art. There certainly seems to be some connection, however it may be explained. The explanation, when it arrives, will, however, be a genuine one, and not on the lines of the late Mr. Donnelly's "Atlantis," with its curious comparisons of Maya signs with "Egyptian hieroglyphics," most of which had no real existence. It is a pity that the investigation of possible connections between Mexican culture and those of the rest of the world has been so seriously discredited by the "Atlantis" idea. Miss Breton's description of the Xochicalco temple is interesting reading.

Mr. Gordon describes, among other "ploys" of the Eskimo, their elaborate cat's-cradle games. From a personal trial we cannot say that his recipes for their production are as clearly put as they might be. The photographs of these Eskimo which Mr. Gordon publishes show a Mongol rather than American type; plate v., 2, might, but for the eyes being rather too deeply set, be a Japanese.

The Cretan contribution is a good article on "The Decorative Art of Crete in the Bronze Age," by Miss Edith H. Hall, who worked at Gournià with Miss Boyd (Mrs. Hawes). As a succinct description of the most striking characteristics of the succeeding "Minoan" periods of Cretan artistic development it is very useful, and supplements Dr. Evans's "Essai de Classification" and Dr. Mackenzie's articles on pottery in the "Journal of Hellenic Studies" and the "Annals of the British School at Athens." In tone Miss Hall is perhaps just a trifle too dogmatic, and dismisses the opinions of others (e.g. Messrs. Hogarth and Welch once or twice) too summarily. On Egyptian matters, too, she is inclined to regard as certain what those who deal with Egyptian things at first-

1 University of Pennsylvania : Transactions of the Department of Archæ ology. Free Museum of Science and Art, vol. ii., nart i. Pp. 105; 29 plates. (Philadelphia: Published by the Department of Archæology, Igo6.) Price

NO. I99I, voL. 77] hand know to be thoroughly uncertain. The later system of Egyptian dates is adopted (p. 12) from Prof. Breasted's history with hardly a qualm, in spite of the fact that it is not yet accepted by Petrie, Maspero, von Bissing, or Budge (to give only the most prominent names). There are growing reasons in favour of it, true; but equally there are most serious considerations to be urged against it. To talk dogmatically of the VIth Dynasty as ending "in 2475 B.c." (the italics are mine), or the XIIth as dating "from 2000 to 1788 B.c.," is absurd, though Miss Hall is not responsible for the absurdity.

Also, Miss Hall makes the usual mistake of the Greek archæologist, a mistake which we had occasion to correct in the case of her colleague Mr. Seager last year, in persistently regarding all Egyptian representations of plants, flowers, and so forth, as stiff and conventional. They are not invariably so, as a study of plant designs on XVIIIth Dynasty pottery from Deir el-Bahari and elsewhere shows; it is these, and not the formal dadoes of papyrus plants in wall paintings, that we must compare with the plant designs of the Cretan artists. Miss Hall's Fig. 29 is quoted as a Cretan " adaptation of the lotus clumps of Egyptian art. Here the method of arranging the flowers," she says, " is the same as in Egyptian art, yet every trace of Egyptian stiffness is gone." I could quote several examples of Egyptian representations of flowers that are far less stiff and formal than this Cretan one. The designs of Figs. 35,48, and 49 could all be paralleled on Egyptian pottery.

Miss Hall's classificatory table of "Cretan Bronze Age Design" is very useful as a conspectus of the chief examples of the designs of the "Minoan" periods.

\section{H. R. Hall.}

\section{THE PELYCOSAURIAN REPTILES. ${ }^{1}$}

$A$ LMOST exactly thirty years ago the late Prof. Cope brought to the notice of the scientific world remains of certain remarkable carnivorous reptiles from the Permian strata of Texas, for which he proposed the group-name Pelycosauria. The group was regarded as a suborder of the Rhynchocephalia, and was provisionally taken to include the theriodont reptiles of South Africa. Among the more typical representatives of the pelycosaurs are Dimetrodon and Naosaurus, extraordinary reptiles in which the dorsal spines of the trunk vertebræ are so enormously elongated (sometimes with the addition of transverse projections) that they exceed in height the depth of the body below them. Restorations of both the skeleton and the external form have now rendered these creatures familiar even to the man in the street.

As to the systematic position of these reptiles and their kindred, considerable diversity of view has obtained. By many writers they are classed with the theriodont anomodonts, but this, according to modern ideas, is altogether unjustifiable, the structure of the temporal arches in the two groups being different. Dr. Case therefore reverts to the original view that pelycosaurs form a primitive section of the rhynchocephalians.

The group is of special interest as illustrating, perhaps better than any other, the rapid evolution from a generalised type to a complex organisation that may have been the potential cause of early extinction, the life of these reptiles being coterminous with the duration of the Permian epoch. Why these specialised structures were evolved within such a comparatively short time is a subject upon which we can only conjecture. Carnivorous in habit, and easily masters of their contemporaries, these reptiles, Mr. Case suggests, may have developed their spines from mere exuberance of growth from a utilitarian beginning, but that these structures eventually became useless cannot be doubted.

That pelycosaurs existed outside of North America is proved by the occurrence of Naosaurus in the Permian of Bohemia and of Stereorhachis in that of France, while certain reptiles from central Germany may also belong to the group. On the other hand, they are unknown in South

1 "Revision of the Pelycosauria of North America." By E. C. Case Puhlication No. 55. Pp. 176+35 plates. (Carnegie Institution, Washington,
D.C., 1907.) 